\title{
RANCANGAN GAME KREATIF STRATEGY DALAM BENTUK APLIKASI MULTIMEDIA INTERAKTIF PADA MTs. NEGERI 32 JAKARTA
}

\author{
Rudi Rivaldo Sembiring ${ }^{1)}$, Ari Saputro ${ }^{2)}$ \\ ${ }^{1}$ Manajemen Informatika, Fakultas Teknologi Informasi, Universitas Budi Luhur \\ ${ }^{1,2} \mathrm{Jl}$. Raya Ciledug, Petukangan Utara, Kebayoran Lama, Jakarta Selatan 12260 \\ E-mail : rudizaoldyeck@gmail.com ${ }^{1)}$, ari.saputro@budiluhur.ac.id ${ }^{2)}$
}

\begin{abstract}
Abstrak
Untuk meningkatkan pikiran secara kreatif diperlukan berbagai terobosan, baik dalam pengembangan kegiatan sehari-hari, motivasi belajar,dan pemenuhan sarana serta prasarana pendidikan.Dengan Memanfaatkan kemajuan teknologi informasi dan komunikasi khususnya teknologi komputer dalam kegiatan sehari-hari di sekolah atau di lingkungan rumah diharapkan dapat mengembangkan pola pikir, kreativitas para siswa dan dapat memberikan hiburan terhadapap siswa. Penulis membuat sebuah Game Interaktif untuk mendorong siswa agar dapat berpikir secara kreatif dan memberikan hiburan kepada siswa. Oleh karena itu, penulis melakukan pengembangan sebuah Game yang menggabungkan, Object 3D yang di buat dengan software Blender, lalu teks, gambar lalu suara dapat diproses dengan aplikasi Unity Game Engine. Hasil akhir dari penulisan laporan ini berupa Game strategy creative genre “Tower Defense” tentang menjaga serangan dari virus. Hasil nya adalah sebuah game operasional yang membantu meningkatkan kreativitas pemain. Sebagai tambahan penulis membuat stationary berupa Sticker dan Poster untuk tempat riset.
\end{abstract}

Kata kunci: Game, Game Interaktif, Hiburan Kreatif, Animasi, Multimedia, Multimedia Interaktif

\section{PENDAHULUAN}

Perkembangan teknologi di Era modern ini sangat pesat. Berbagai kemajuan teknologi dapat kita dapatkan dengan mudahnya. Seiring dengan perkembangan kehidupan dan pesatnya perkembangan teknologi itu manusia dapat mencari cara untuk mencari kegiatan yang menyenangkan atau dapat menghibur diri sendiri dengan berbagai alat atau sarana, salah satunya sarana untuk penyegaran, seperti bermain game.

MTs. Negeri 32 Jakarta merupakan sekolah umum setingkat SMP plus berciri khas agama islam.Kurikulum MTsN 32(KTSP) merupakan gabungan kurikulum Pendidikan Nasional dan kurikulum Kementerian Agama diperkaya dengan kurikulum Muatan Lokal yang semula berspefikasi pada keunggulan bidan bahasa Inggris/Arab dan Sains yang dimotori kepala Madrasah pertama nya, Drs. Nurul Huda. M.Si (menjabat dari 2003-2011).

Oleh karena itu, penulis membuat sebuah media interaktif berupa aplikasi game interaktif pada MTS.32 Jakarta dengan judul "Rancangan Game Kreatif Strategy Dalam Bentuk Aplikasi Multimedia Interaktif Pada Mts. Negeri 32 Jakarta.”. Sehingga dengan membuat game ini diharapkan para siswa dapat menghilangkan kejenuhan setelah selesai belajar, menghibur para siswa dan meningkatkan kreativitas para siswa.

Pada MTs.Negeri 32 Jakarta belum ada multimedia interaktif yang berupa game bergenre Tower Defense dan diharapkan para siswa yang telah memainkan game ini diharapkan dapat mengurangi kejenuhan yang dialami oleh para siswa dengan memberikan tampilan, efek, dan sound effect yang menarik bagi para siswa.

Tujuan Riset dan penulisan yang telah penulis buat dari hasil riset, bertujuan untuk laporan eksperimen dalam membuat media publisitas berupa bentuk Exe. Mencoba untuk memberikan bahan pengetahuan dari ilmu yang telah di terima selama kuliah di D3 unggulan Universitas Budi Luhur.

Media Game Interaktif merupakan satu dari sekian banyak media yang dapat digunakan untuk memberikan hiburan kepada siswa dengan tampilan, efek yang menarik Keunggulan dari game interaktif ini adalah para siswa dapat berinteraksi langsung terhadap game yang dibuat oleh penulis, dan pada game ini adalah bergenre "Tower Defense" sehingga para siswa di perlukan berpikir kreatif dan mengatur strategy dalam menjaga serangan dari virus.

Multimedia Interaktif menurut beberapa ahli adalah sebagai berikut :

1. Multimedia interaktif adalah alat yang dapat menciptakan persentasi yang dinamis dan interaktif, yang mengkombinasikan tulisan, grafik, animasi, audio dan gambar video [1].

2. Multimedia interaktif adalah pemanfaatan komputer untuk membuat dan menggabungkan teks, grafik, audio, gambar bergerak (video dan animasi) dengan menggabungkan link dan tool yang 
memungkinkan pemakai melakukan navigasi, berintraksi, berkreasi dan berkomunikasi [2].

Jenis Multimedia Interaktif terbagi menjadi dua bagian, yaitu:

1) Multimedia Interaktif Online Multimedia interaktif online adalah media interaktif yang cara penyampaiannya dengan cara jalur/kawat/ saluran/jaringan. Contohnya situs Web, Yahoo Messengers, dan lain sebagainya. Jenis media ini termasuk media lini atas, yang komunitas sasarannya luas, dan mencakup masyarakat luas.

2) Multimedia Interaktif Offline Multimedia interaktif offline adalah media interaktif yang cara penyampainnya tidak dengan jalur/kawat/saluran/jaringan. Contohnya CD interaktif, Media Pembelajaran. Media ini termasuk media lini bawah karena sasarannya, tidak terlalu luas dan hanya mencakup masyarakat pada daerah tertentu saja [3]. Fungsi Multimedia Interaktif adalah beberapa sebagai berikut

1. Komunikasi antar bisnis: manajemen, absensi, keuangan.

2. Komunikasi bisnis dan konsumen: ecommerce.

3. Komunikasi antar konsumen: jejaring sosial.

4. E-Learning: training, alat bantu pengajaran, media pembelajaran.

5. Hiburan: games.

6. Komunikasi pemerintah: informasi publik, layanan masyarakat.

7. Komunikasi kebudayaan: informasi museum dan galeri [4].

Unsur-Unsur multimedia interaktif antara lain :

1. Teks

Teks adalah icon berupa medium visual yang digunakan untuk menjelaskan bahasa lisan. Teks memiliki berbagai macam jenis bentuk atau tipe ( sebagai contoh: Optimus, Tahoma, Arial), ukuran dan wana. Satuan dari ukuran suatu teks terdiri dari length dan size.

Length berarti banyaknya teks dalam sebuah kata atau halaman. Size menyatakan ukuran besar atau kecil suatu huruf. Standar teks memiliki size 8 atau 14 poin. Semakin besar angka yang kita buat maka suatu huruf semakin tampak besar ukuran huruf tersebut.

2. Grafik

Grafik adalah suatu medium berbentuk visual. Setiap gambar dua dimensi adalah grafik. Apabila gambar di render dalam bentuk tiga dimensi (3D), maka tetap disajikan melalui medium dua dimensi. Hal ini termasuk gambar yang disajikan lewat kertas, televisi ataupun layar monitor. Grafik bisa saja menyajikan kenyataan (reality) atau hanya berbentuk iconic. Contoh grafik yang menyajikan kenyataan adalah foto dan contoh grafik yang berbentuk iconic adalah kartun seperti gambar yang biasa kita liat di rambu-rambu lalu lintas dimana ada icon untuk berhenti maupun untuk berbelok atau tetap maju.Grafik terdiri dari gambar yang tidak bergerak dan gambar bergerak. Contoh dari gambar diam yaitu foto, gambar digital, lukisan, dan poster. Gambar diam biasa diukur berdasarkan size (sering disebut juga canvas size) dan resolusi. Contoh dari gambar bergerak adalah animasi, video dan film. Selain bisa diukur dengan menggunakan size dan resolusi, gambar bergerak juga memiliki durasi.

3. Audio

Audio atau medium berbasis suara adalah segala sesuatu yang mengeluarkan suara yang bisa didengar dengan menggunakan indera pendengaran. Contoh: narasi, lagu, soundeffect, backsound.

4. Interaktivitas

Interaktivitas tidak berbasis medium, interaktivitas adalah rancangan dibalik suatu program multimedia.

Interaktivitas mengijinkan seseorang untuk membuka berbagai macam bentuk media atau jalur didalam suatu program multimedia sehingga program yang ada dapat lebih berarti dan lebih memberikan kepuasan bagi pemakai aplikasi tersebut.

\section{Animasi}

Animasi ialah bentuk dari gambar bergerak yang berupa susunan dari objek/gambar itu sendiri yang ditampilkan secara bergantian menjadikan objek terlihat seolah hidup, animasi sendiri memiliki arti berupa jiwa, hidup, semangat, yang berasal dari kata latin yaitu "anima". animasi sangat digemari tidak hanya oleh anak-anak bahkan orang dewasa sekalipun sebab sifat dari animasi dapat menarik perhatian banyak orang untuk menghilangkan rasa jenuh dan bosan.Animasi juga dapat membuat kita merasa bersemanganat dan takjub saat melihat suattu gambar yang bergerak [5].

\section{METODE PENELITIAN}

\subsection{Objek Penelitian}

MTSn 32 Jakarta belum memiliki media Game interaktif sebagai media hiburan bagi siswa yang akan di teliti oleh penulis, sehingga penulis memberikan ajuan sebuah pembuatan media Game interaktif. Penulis merancang dan membuat tampilan multimedia interaktif sebagai media Game interaktif dengan tema Tower Defense.

Terlebih pada media cetak berupa stationary yang telah dipakai pada MTSn 32 Jakarta, menggunakan format desain yang dibuat sendiri oleh 
penulis lalu di gabungkan dengan logo pada MTSn 32 Jakarta.

\subsection{Analisa Objek}

Karena objek yang akan diteliti belum ada pada MTSN 32 Jakarta, maka dari itu penulis berinisiatif untuk membuat sebuah media game interaktif untuk menunjang pola pikir, kreatif dan memberikan hiburan kepada siswa pada MTSN 32 Jakarta. Tujuan dari pembuatan game interaktif ini adalah untuk menunjukkan kepada para tenaga pengajar, orang tua maupun para siswa kalau IT dapat membuat berbagai macam hal contoh nya seperti game yang di buat oleh penulis, sehingga anak dapat mengerti dan paham peran penting teknologi informasi dalam hal yang positif.

Kendala yang dihadapi dalam pembuatan game interaktif ialah belum adanya objek maupun ide penelitian sebelumnya dan belum adanya game berbasis multimedia interaktif sehingga penulis harus menempatkan desain tampilan,efek-efek yang menarik dan dapat di terima oleh para siswa. Dan penulis menggunakan blender software untuk mendesign 3D dan software Unity Game Engine untuk membuat tampilan Game interaktif.

Disamping ada nya kendala tersebut dalam pembuatan game interaktif juga ada kelebihan yang di dapat yaitu murid-murid dapat berinteraksi langsung dengan game yang dibuat, dan game ini berpacu pada strategy dan kreatif dari pada murid sehingga mengacu pikiran para murid-murid.

Penulis membuat tampilan desain pembelajaran interaktif beserta typografi untuk di implementasikan ke dalam stationary berupa poster, dan sticker. Desain pada poster menggunakan logo MTSN 32 Jakarta disertai tambahan keterangan alamat instansi. Begitu pula dengan desain sticker.

\subsection{Konsep Desain}

Pada bagian proposal konsep desain penulis akan menjelaskan tujuan dan struktur project yang akan dibuat sebelum kegiatan dimulai. sasaran dan batasan yang dituju mengenai desain yang dibuat berdasarkan penyelesaian masalah.

Sasaran dan batasan yang dituju dari kegiatan ini antara lain :

a. Riset ini hanya membuat tampilan multimedia interaktif dengan satu tema yang digunakan sebagai contoh aplikasi interaktif dalam bentuk game.

b. Stationary yang dibuat adalah Poster dan Sticker.

Tujuan dari kegiatan ini antara lain :

a. Membuat desain tampilan game interaktif untuk MTSN 32 Jakarta.

b. Membuat stationary.

\subsection{Metodologi}

a. Desain Karakter

Pertama saya membuat karakter dan membuat jenis-jenis dari tower yang akan digunakan di game dengan software blender yang bertujuan menarik minat para siswa dan siswi.

b. Penggabungan Karakter

Penggabungan Karakter, background yang berbeda tiap level dan tower-tower yang digunakan menjadi satu dan di taruh pada scene nya masing-masing dan itu terapkan pada software Unity Engine.

c. Penambahan Audio

Penambahan sound effect dan lagu yang di download di masukkan ke dalam Unity Engine.

d. Penambahan C\#

Penambahan C\# yang membuat virus bergerak, tower yang yang menembakkan peluru nya, mengikuti target, damage yang di hasilkan tiap tower, health point yang dimiliki musuh, timer, dan tombol button juga menjadi tombol yang dapat di click oleh user seperti tombol memilih tower, dan tombol pause.

e. Penambahan Efek

Penambahan Efek dilakukan di Unity Engine seperti efek meteor, petir, dan salju. Di Unity Engine juga di buat efek menembak tower, virus hancur, dan efek ketika kita membangun dan menjual tower.

f. Finishing Multimedia Interaktiff

Dan yang terakhir melakukan render pada game yang di buat pada Unity Engine dan menjadi kan nya file Exe, lalu menjalankan projek yang telah kita buat.

\subsection{Rancangan Layar}

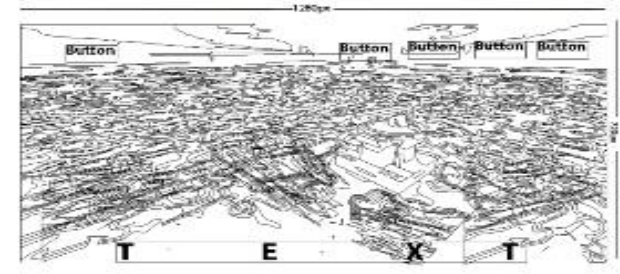

Gambar 1. Rancangan Layar Menu

Pada Gambar 1 menjelaskan ketika layar menu muncul kita dapat memilih 4 tombol menu 1 menu exit

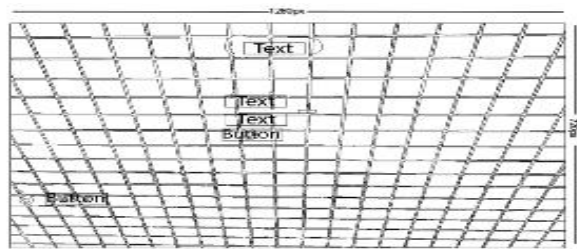

Gambar 2. Rancangan Layar Option 
Pada Gambar 2 menjelaskan ketika kita masuk ke menu option untuk memilih menu full screen dan mengatur volume beserta tombol back.

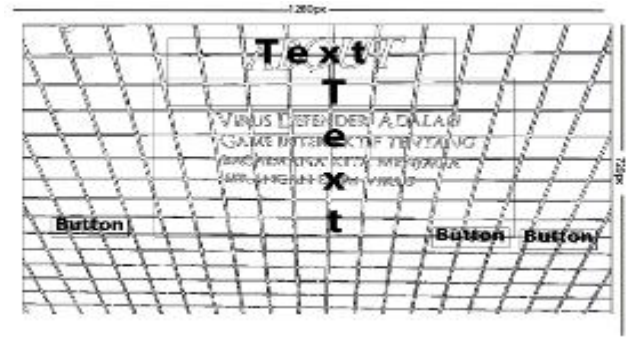

Gambar 3. Rancangan Layar Menu About

Pada Gambar 3 menjelaskan ketika kita masuk ke menu about yang berisi tentang apa itu "virus defender" dan ucapan terima kasih dengan menekan button next yang ada beserta tombol exit.

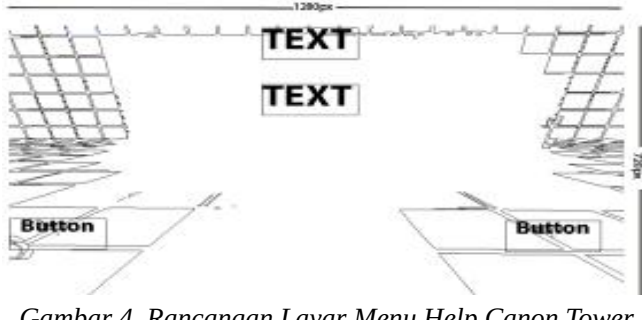

Pada Gambar 4 menjelaskan ketika kita masuk ke menu help yang berisi tentang informasi Rocket Tower dan dengan menekan tombol next yang ada kita dapat melihat tower yang berbeda beserta tentang penjelasan dari kegunaan tower yang ada beserta tombol back untuk kembali ke menu utama.

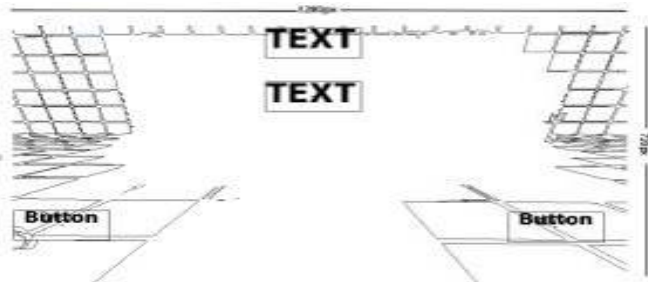

Gambar 5. Rancangan Layar Menu Help Rocket Tower

Pada Gambar 5 Menjelaskan menu help Rocket Tower dan ada tombol back dan next.

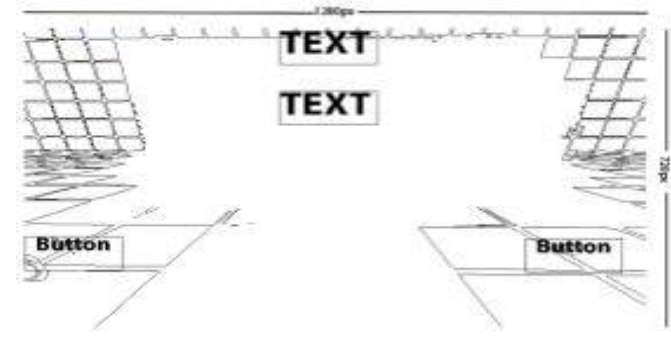

Gambar 6. Rancangan Layar Menu Help Laster Tower
Pada Gambar 6 menjelaskan ketika kita masuk ke menu help yang berisi tentang informasi Laser Tower dan ada tombol back dan next

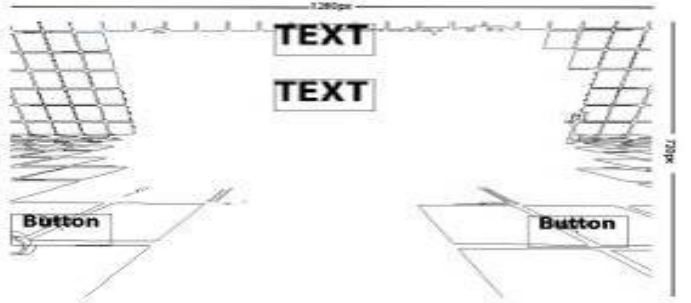

Gambar 7. Rancagan Layar Menu Help Laser Beam Tower

Pada Gambar 7 menjelaskan ketika kita masuk ke menu help yang berisi tentang informasi Laser Beam Tower beserta ada tombol next dan back.

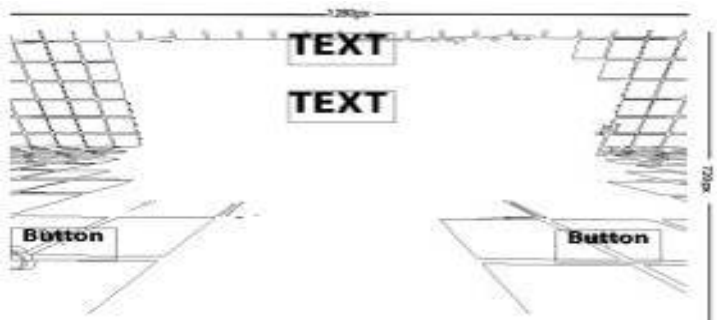

Gambar 8. Rancagan Layar Menu Help Double Launcer Tower

Pada Gambar 8 menjelaskan ketika kita masuk ke menu help yang berisi tentang informasi Double Launcher Tower dan dengan menekan tombol menu yang akan membawa kita kembali ke menu utama nya dan ada tombol back untuk kembali ke menu tower sebelumnya

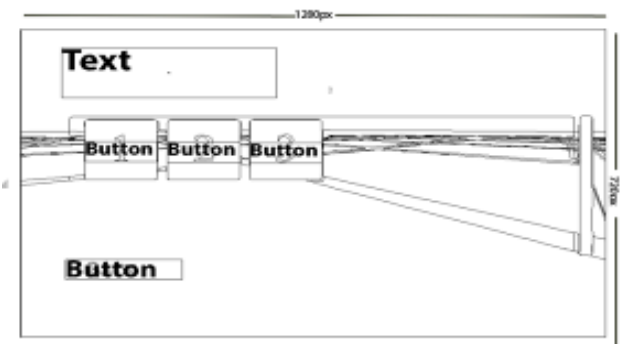

Gambar 9. Select Level

Pada Gambar 9 menjelaskan ketika kita masuk ke menu play dan menampilkan 3 pilihan level yang dipilih oleh user dan ada tombol back yang akan membawa kita kembali ke menu utama 


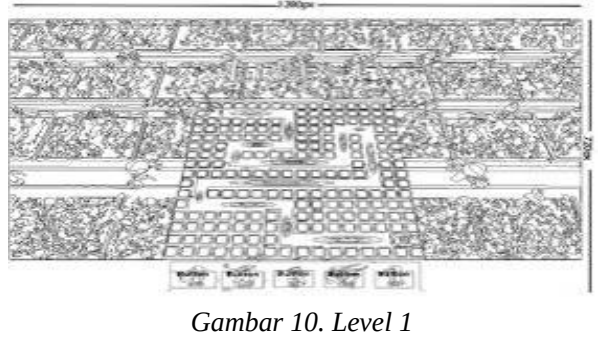

Pada gambar 10 menjelaskan ketika kita ada di level 1 di level 1 kita sudah dapat memainkan game yang dibuat, dan terdapat 5 tombol yang di dapat di klik untuk memilih tower yang kita inginkan beserta ada timer nya juga.

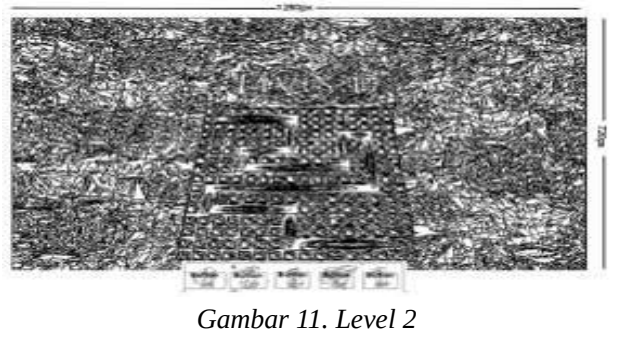

Pada gambar 11 menjelaskan ketika kita ada di level 2 di level 2 ini terdapat background yang berbeda dan terdapat 5 tombol yang di dapat di klik untuk memilih tower yang kita inginkan beserta ada timer nya juga.

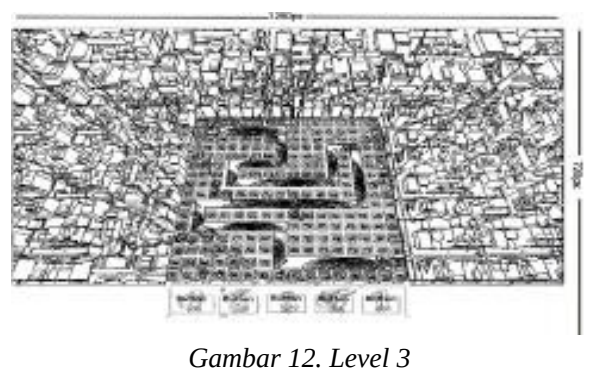

Pada gambar 12 menjelaskan ketika kita ada di level 3 di level 3 ini terdapat background yang berbeda dan terdapat 5 tombol yang di dapat di klik untuk memilih tower yang kita inginkan beserta ada timer nya juga

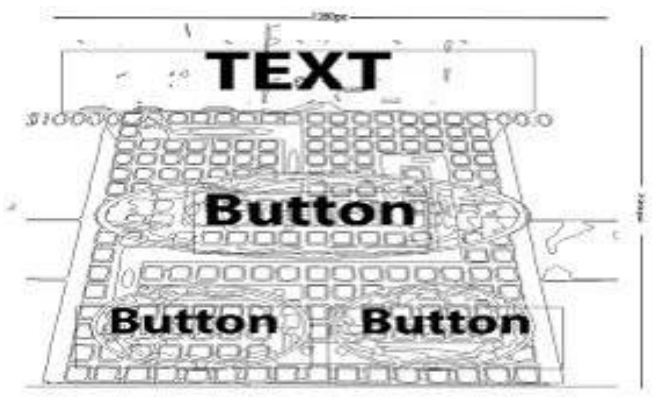

Gambar 13. Pause Menu
Pada gambar 13 menjelaskan ketika memencet tombol keyboard "ESC" dan muncul Pause menu yang berfungsi memberhentikan game dan terdapat 3 tombol yang dapat di klik

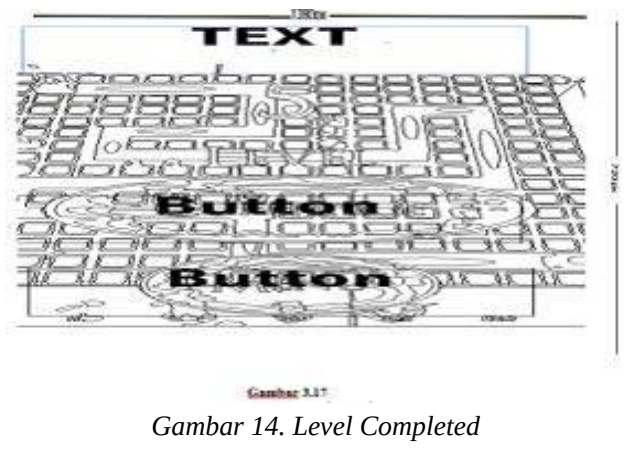

Pada Gambar 14 menjelaskan ketika selesai menyelesaikan sebuah level dan muncul 2 tombol yaitu Continue yang berfungsi untuk lanjut ke level selanjut nya dan menu untuk kembali ke menu utama

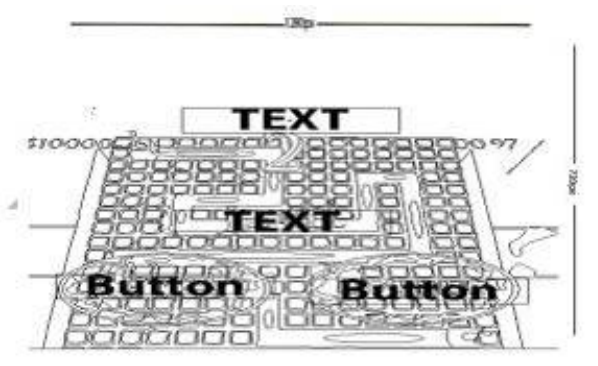

Gambar 15. Game Over

Pada Gambar 15 menjelaskan ketika kalah atau gagal menyelesaikan level dan muncul 2 tombol yaitu Retry untuk mengulang kembali level dan menu untuk kembali ke menu utama.

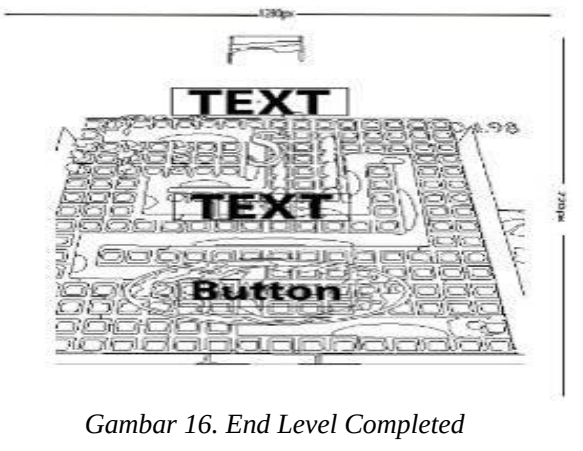

Pada Gambar 16 menjelaskan ketika telah menyelesaikan semua level yang ada dan muncul layar beserta 1 tombol yaitu tombol Menu yang berfungsi untuk kembali menu utama. 


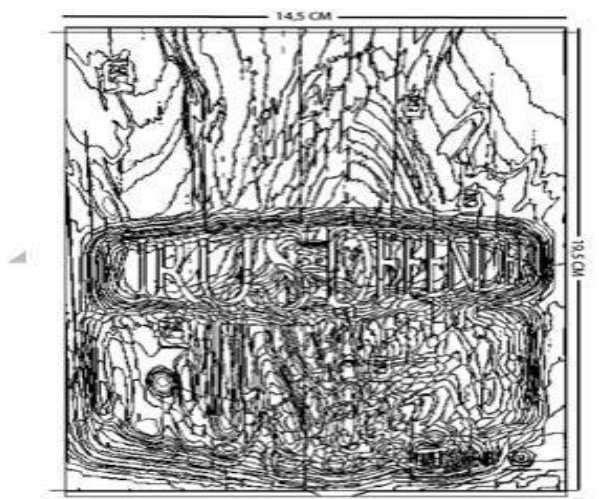

Gambar 17. Rancangan Desain Poster Virus Defender

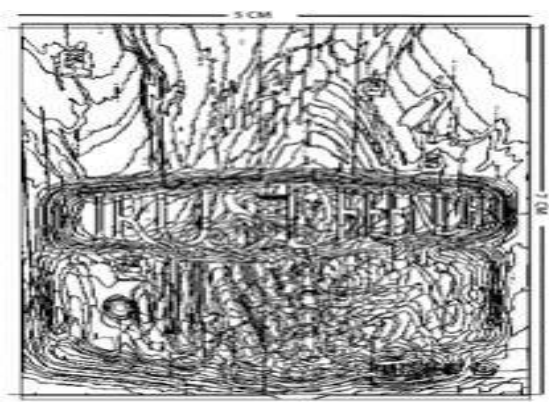

Gambar 18. Rancangan Desain Sticker Virus

$$
\text { Defender }
$$

\section{HASIL DAN PEMBAHASAN}

3.1. Tampilan Unity Engine(Exe)

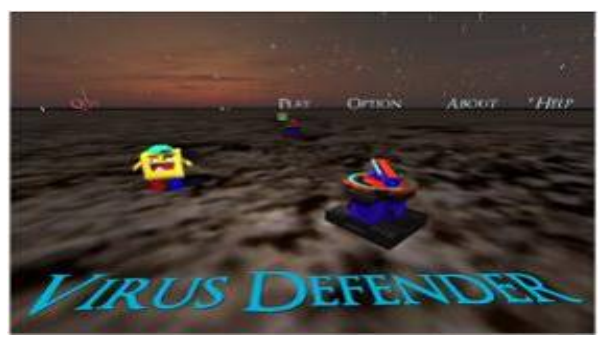

Gambar 19. Main Menu

Gambar 19 Menjelaskan ketika kita setelah membuka file exe dan muncul 4 menu dan 1 menu exit yang dapat di klik.

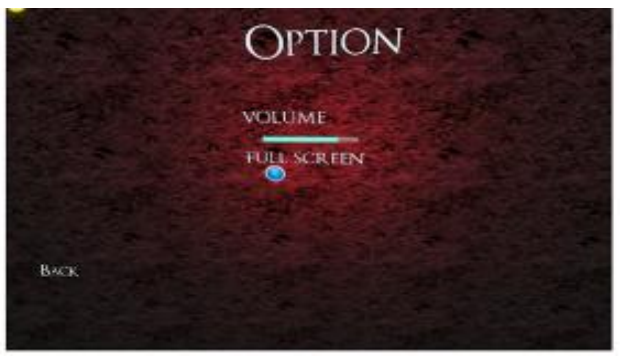

Gambar 20. Menu Option
Gambar 20 Menjelaskan ketika masuk ke menu option untuk mengatur volume dan tombol full screen, beserta tombol back.

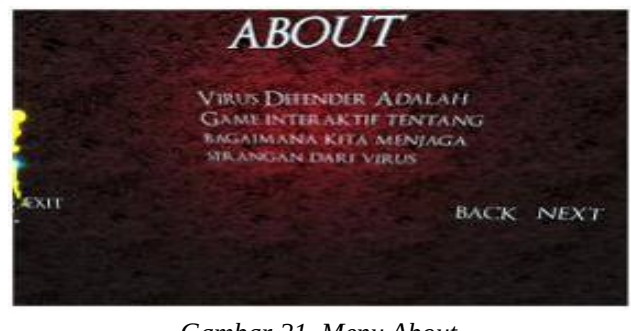

Gambar 21. Menu About

Gambar 21 Menjelaskan ketika masuk ke menu about untuk penjelasan apa itu virus defender da nada tombol exit untuk kembali ke menu utama

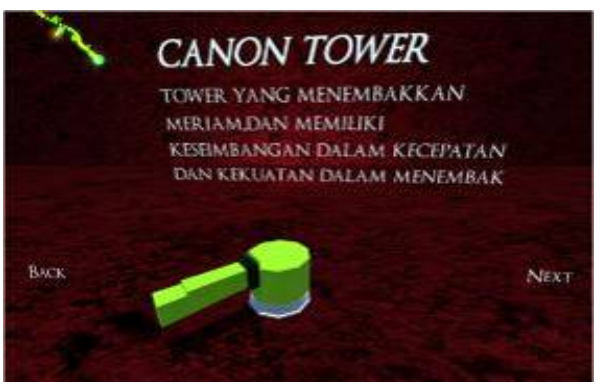

Gambar 22. Menu Help Canon Tower

Gambar 22 Menjelaskan ketika masuk ke menu help dan penjelasan nya yang muncul di awal adalah Canon Tower dan terdapat tombol back dan next

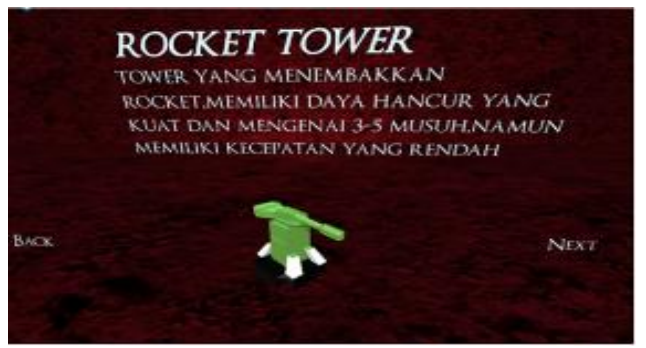

Gambar 23. Menu Help Rocket Tower

Gambar 23 Menjelaskan Rocket Tower dan ada tombol back dan next

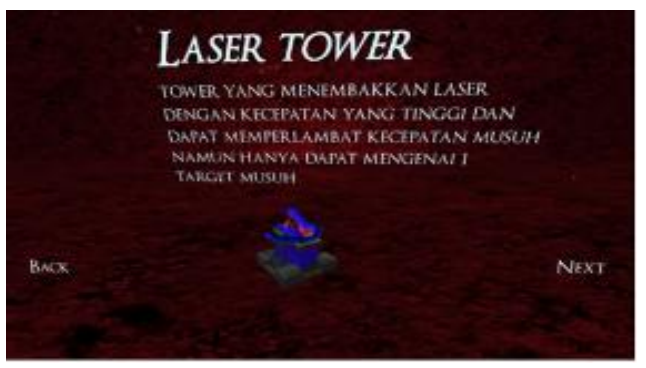

Gambar 24. Menu Laser Tower 
Gambar 24 Menjelaskan Laser Tower dan ada tombol back dan next

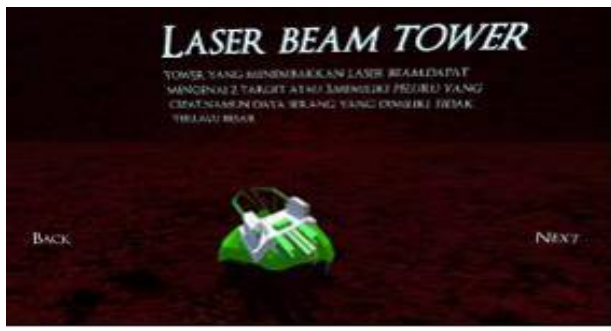

Gambar 25. Menu Laser Beam Tower

Gambar 25 Menjelaskan Laser Beam Tower dan ada tombol back dan next

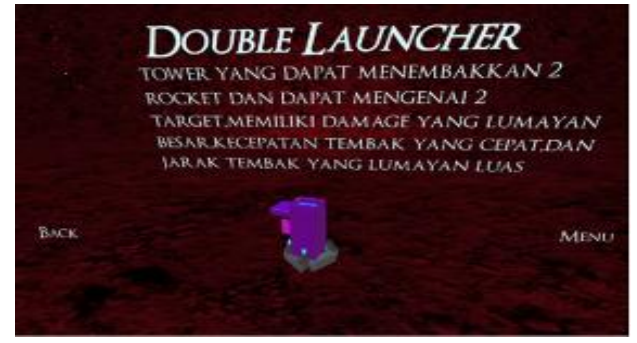

Gambar 26. Menu Double Launcher Tower

Gambar 26 Menjelaskan double launcher Tower dan ada tombol back dan menu untuk kembali ke menu utama

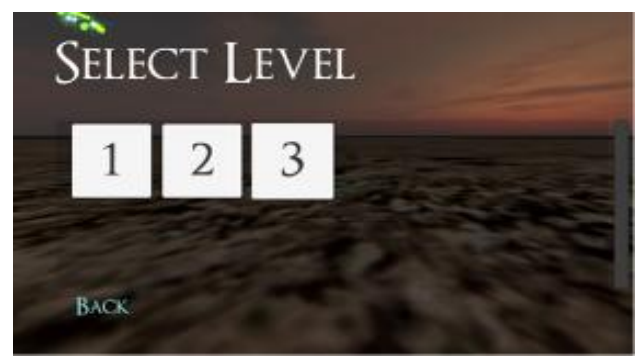

Gambar 27. Select Level

Gambar 27 Menjelaskan Level mana saja yang dapat kita pilih

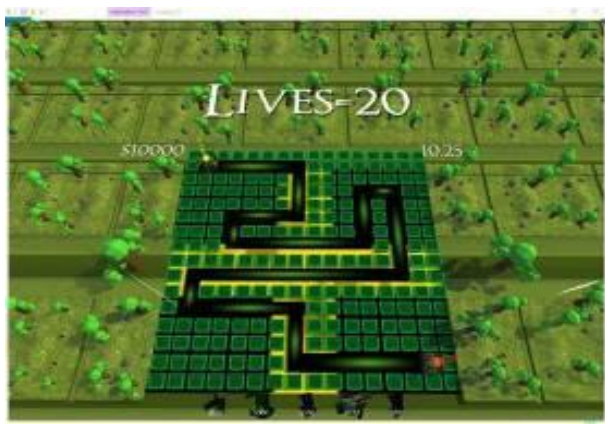

Gambar 28. Level 1
Gambar 28 adalah tampilan dari level 1 dan terdapat 5 button untuk memilih tower

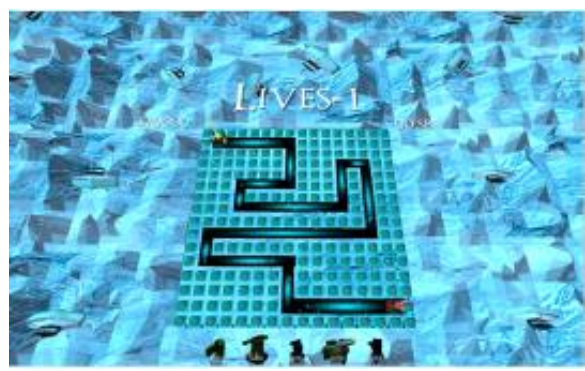

Gambar 29. level 2

Gambar 29 adalah tampilam dari level 2 dan terdapat 5 button untuk memilih tower

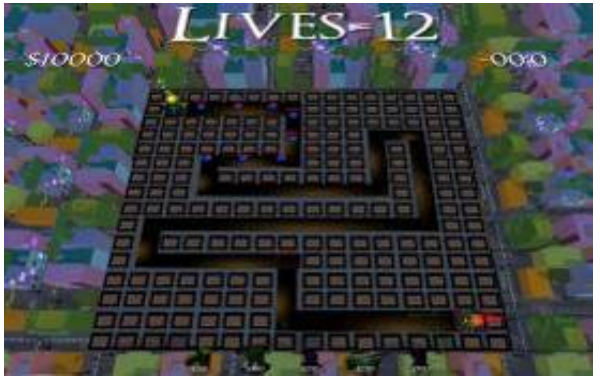

Gambar 30. Level 3

Gambar 30 adalah tampilan dari level 3 dan terdapat 5 button untuk memilih tower

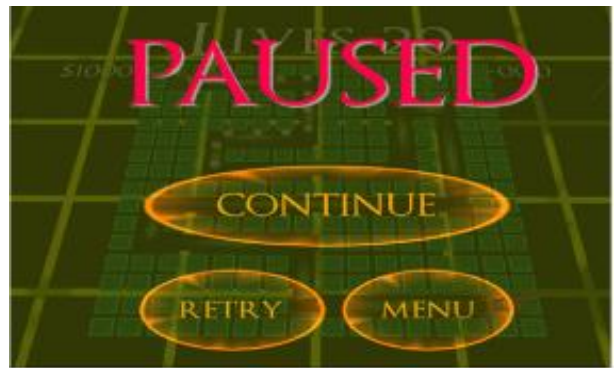

Gambar 31. Pause Menu

Gambar 31 adalah tampilan ketika menekan "ESC" pada saat memulai game dan terdapat 3 button yang dapat di klik

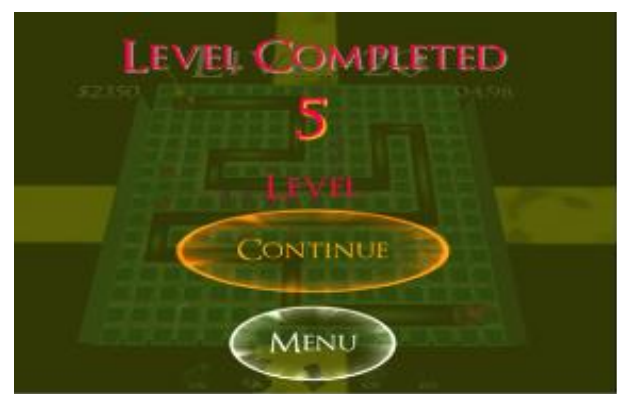

Gambar 32. Level Completed 
Gambar 32 adalah tampilan ketika kita menyelesaikan sebuah level dan tedapat 2 button yang dapat di klik

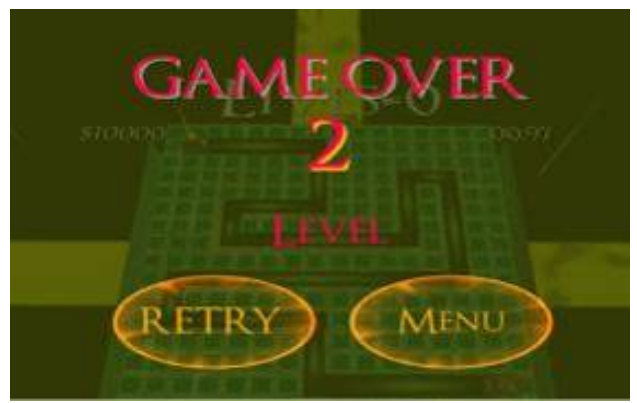

Gambar 33. Game Over

Gambar 33 adalah tampilan ketika kalah dan terdapat 2 button yang dapat di klik

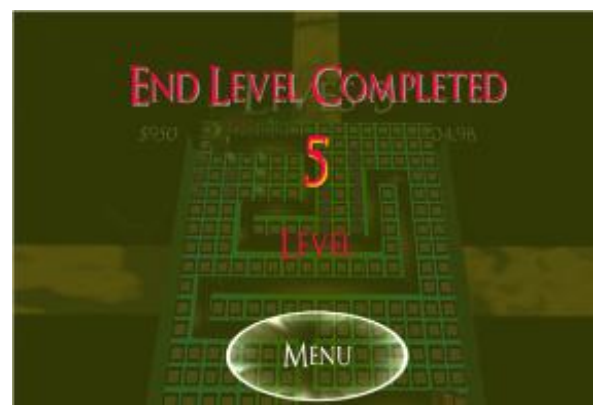

Gambar 34. End Level Completed

Gambar 34 adalah tampilan ketika kita menyelesaikan semua level dan terdapat 1 button yang dapat di klik

\section{KESIMPULAN} berikut:

Penilitian ini dapat di simpulkan sebagai

a. Kurangnya pemanfaatan media dalam memberikan hiburan kepada siswa berakibat kepada siswa menjadi jenuh sehingga membuat keinginan atau semangat belajar para murid berkurang.

b. Media Game interaktif ini dapat memberikan hiburan dan juga membuat para siswa lebih kreativ berpikir seperti menaruh tower yang tepat untuk melawan virus yang di game interaktif ini pada Mtsn 32 Jakarta.

c. Diharapkan Game yang telah di buat ini dapat di tingkatkan lagi seperti menambahkan jenis-jenis tower maupun musuh.

d. Dengan adanya Game interaktif ini beserta tampilan yang menarik dan beda dari yang lain diharapkan para peserta didik di Mtsn 32 Jakarta dapat meningkatkan pola pikir para siswa dan membuat para siswa terhibur e. Pembuatan desain stationary berupa poster, dan sticker menggunakan logo dari Mtsn Jakarta sebagai pelengkap media promosi pada Mtsn 32 Jakarta.

\section{DAFTAR PUSTAKA}

[1] Hofstetter. Pengertian Multimedia Interaktif, McGrawHill International Edition, New York, 2011.

[2] Robin, Linda. Menguasai Pembuatan Animasi dengan Macromedia Flash, Jakarta, Elek Media Komputindo, 2001.

[3] Suyanto. Aplikasi Desain Grafis Untuk Periklan, Yogyakarta, AND, 2011.

[4] Eko, Prabowo. Presentasi Multimedia Dengan Director MX, Jakarta, Elex Media Komputindo, 2003.

[5] Munir. Multimedia, Konsep Dan Aplikasi Dalam Pendidikan. Alfabeta, Bandung, 2012. 